\title{
Size distribution and roundness of clasts within pseudotachylytes of the Gangavalli Shear Zone, Salem, Tamil Nadu: An insight into its origin and tectonic significance
}

\author{
Bhuban Mohan Behera ${ }^{1, *}, \mathrm{~V}$ Thirukumaran ${ }^{2}$, Aishwaraya Soni ${ }^{1}$, \\ Prasanta Kumar Mishra ${ }^{3}$ and Tapas Kumar Biswal ${ }^{1}$ \\ ${ }^{1}$ Department of Earth Sciences, Indian Institute of Technology Bombay, Mumbai 400 076, India. \\ ${ }^{2}$ Department of Geology, Govt. Arts College, Salem 636 00\%, India. \\ ${ }^{3}$ Geological Survey of India, Raipur, Chhattisgarh 492 010, India. \\ *Corresponding author.e-mail: beherabhubanmohan@gmail.com
}

MS received 1 August 2016; revised 5 February 2017; accepted 6 February 2017; published online 6 June 2017

Gangavalli (Brittle) Shear Zone (Fault) near Attur, Tamil Nadu exposes nearly $50 \mathrm{~km}$ long and 1-3 km wide NNE-SSW trending linear belt of cataclasites and pseudotachylyte produced on charnockites of the Southern Granulite Terrane. Pseudotachylytes, as well as the country rock, bear the evidence of conjugate strike slip shearing along NNE-SSW and NW-SE directions, suggesting an N-S compression. The Gangavalli Shear Zone represents the NNE-SSW fault of the conjugate system along which a right lateral shear has produced seismic slip motion giving rise to cataclasites and pseudotachylytes. Pseudotachylytes occur as veins of varying width extending from hairline fracture fills to tens of meters in length. They carry quartz as well as feldspar clasts with sizes of few $\mathrm{mm}$ in diameter; the clast sizes show a modified Power law distribution with finer ones $\left(<1000 \mu \mathrm{m}^{2}\right)$ deviating from linearity. The shape of the clasts shows a high degree of roundness $(>0.4)$ due to thermal decrepitation. In a large instance, devitrification has occurred producing albitic microlites that suggest the temperature of the pseudotachylyte melt was $>1000^{\circ} \mathrm{C}$. Thus, pseudotachylyte veins act as a proxy to understand the genetic process involved in the evolution of the shear zone and its tectonic settings.

Keywords. Pseudotachylyte; clast; Power law distribution; roundness; Gangavalli Shear Zone.

\section{Introduction}

The term Pseudotachylyte was first coined by Shand (1916) following his work in Vredefort crater in South Africa, which refers to a dark coloured glassy material resembling volcanic igneous rock tachylyte. Since then, voluminous work has been done on pseudotachylyte genesis. Ultracataclasis, as the origin of pseudotachylytes (Wenk 1978) has been ruled out, and at present, two modes of formation are described (which is still a debatable topic); (i) impact melting (Grieve 1975; Bischoff 1982; Reimold and Collision 1992; Spray and Thompson 1995; Pati et al. 2015) and (ii) frictional melting during shearing (Sibson 1975; Cardwell et al. 1978; Spray 1992; Swanson 1992; Biswal et al. 2004; Kirkpatrick et al. 2012). Authors like Han et al. (2010), Ujiie et al. (2011), Niemeijer et al. (2012) and Rowe et al. (2012) described development of pseudotachylytes by characterizing and 
comparing field observations to the products of fast slip rate rock friction experiments.

Pseudotachylyte is formed due to high strain rate along the fault plane which is mostly $1-10 \mathrm{~m} / \mathrm{s}$ (McKenzie and Brune 1972; Sibson 1975; Passchier 1982; Magloughlin 1992). During this deformation, an ultra-high temperature is generated due to friction which can melt the crushed materials. Different minerals melt at different temperatures, e.g., biotite at $\sim 800^{\circ} \mathrm{C}$, plagioclase at $\sim 1400^{\circ} \mathrm{C}$ and finally quartz at $\sim 1700^{\circ} \mathrm{C}$ (Jiang et al. 2015). The melt moves through fractures and quenches to produce a glassy material in contact with the cold host rock. Devitrification of pseudotachylyte shows microcrystals like microlite and spherulites (Philpots 1964; Spray 1992) to provide an evidence of melt origin of pseudotachylyte.

It is generalized that pseudotachylytes are mostly associated with clasts of the country rock. The distribution of survivor clasts in the pseudotachylyte follows a certain law which is called 'modified Power law distribution' (Spray 1992; Bizzarri 2014) and this paper aims at addressing the clast-size and shape analysis of pseudotachylytes, which aids the knowledge of origin of the pseudotachylytes of the Gangavalli Shear Zone in the Southern Granulite Terrane of India. Further, it throws light on the tectonic setting of Gangavalli Shear Zone vis-a-vis other shear zones of the terrane.

\section{Geology of the area}

Gangavalli Shear Zone (GSZ) is a brittle shear zone or a fault that runs for nearly $50 \mathrm{~km}$ in the NNE-SSW direction close to Attur and Gangavalli towns of Tamil Nadu in India (figure 1 and inset). It has a variable width from few hundreds of meters to a few kilometers and occupies a series of hills between the Kollimalai, Panchamalai and Kalrayan Hills. In the western side of the GSZ, there lies a number of ENE-WSW running ductile shear zones; however, to the east there is no such shear zone (Sundaralingam et al. 2012). Hence, it has been opined that GSZ divides Southern Granulite Terrane into a Western and Eastern Block that probably belongs to two different ages. The GSZ on its northern side merges with the boundary of the Eastern Ghats Mobile Belt. The ductile shear zones in the western block including the Kanjamalai Shear Zone, Udayapatti Shear Zone and Vembagoundam Pudur Shear Zone, combined, are known as the Salem-Attur Shear Zone are associated with mylonites; the mylonites are characterized by several mylonitic fabric namely S-C fabric, intragranular faults and feldspar porphyroclasts that point to northeasterly vergent thrust slip nature. Thrusting has brought the charnockites of Salem-Namakkal Block over the Sevroy Block in the form of stack of granulite nappes (Biswal et al. 2009; Sundaralingam et al. 2012). Sweta Nadi Shear Zone shows reactivation and overprinting of brittle deformation on ductile structures, thus cataclasites and pseudotachylytes are associated with it. In fact, pseudotachylyte veins are observed at several places in the Southern Granulite Terrane (Bhaskar Rao et al. 2006; Thirukumaran et al. 2014); however, a larger concentration is observed at the GSZ where voluminous pseudotachylytes are emplaced. The GSZ is developed on charnockitic host rock, which represents granulite facies metaigneous rock that has mineral assemblages of quartz, K-feldspar, plagioclase and hypersthene. The rock is coarse-grained and carries gneissosity fabric marked by alternate dark bands where hypersthenes are segregated and white bands where felsic minerals are concentrated. The gneissosity fabric runs in ENE-WSW direction with varying dips. Charnockites show an emplacement age of ca $2600 \mathrm{Ma}$ and the granulite facies metamorphism has taken place at ca $2400 \mathrm{Ma}$ (Clark et al. 2009). At places, dolerite dykes and granite plutons of ca $1875 \mathrm{Ma}$ (Sundaralingam 2013) have intruded into the charnockites; they do not show the effect of metamorphism, however, they have undergone brittle deformation. The brittle deformation is thus $<1875 \mathrm{Ma}$ old. The $\mathrm{Ar}^{40} / \mathrm{Ar}^{39}$ age of pseudotachylytes from Salem area has been determined to be $904 \pm$ 43 to $1286 \pm 33 \mathrm{Ma}$ with the weighted mean age of $1108 \pm 46 \mathrm{Ma}$ (Bhaskar Rao et al. 2006). The GSZ is marked by extensive fracturing and grinding of the charnockites, the fractures are predominantly developed in a conjugate manner in NNE-SSW and NW-SE direction (figure $2 \mathrm{a}, \mathrm{b}, \mathrm{d})$. In the same outcrop, both sets are developed; the $\mathrm{N}-\mathrm{S}$ fractures show sinistral shear, while NW-SE sets show dextral shear, suggesting a compressive stress in $335^{\circ}$ direction (figure 2a). The fractures also occur in the adjoining terrane outside the GSZ, both in small as well as in large scale in the form of lineament (Thirukumaran et al. 2014). The fractures from outcrop to microscopic scale vividly display mutual displacement character as an evidence of 


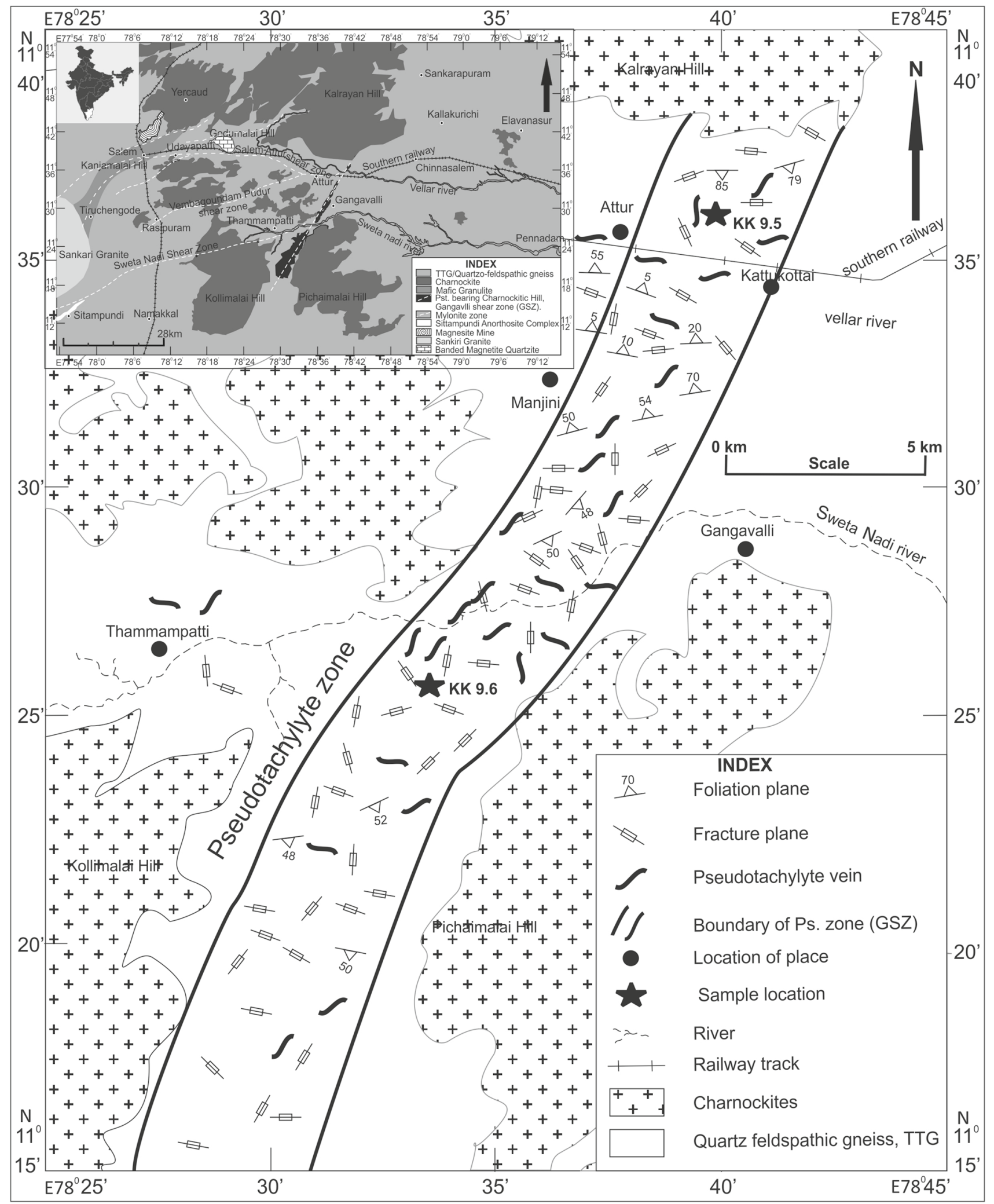

Figure 1. The structural map of Gangavalli Shear Zone (fault) with sample location of pseudotachylyte. (Inset) Regional geological map of Salem-Attur-Namakkal area, Southern Granulite Terrane (modified after Sundaralingam 2013). Gangavalli Shear Zone is marked by NE-SW trending pseudotachylyte bearing charnockite hills. 


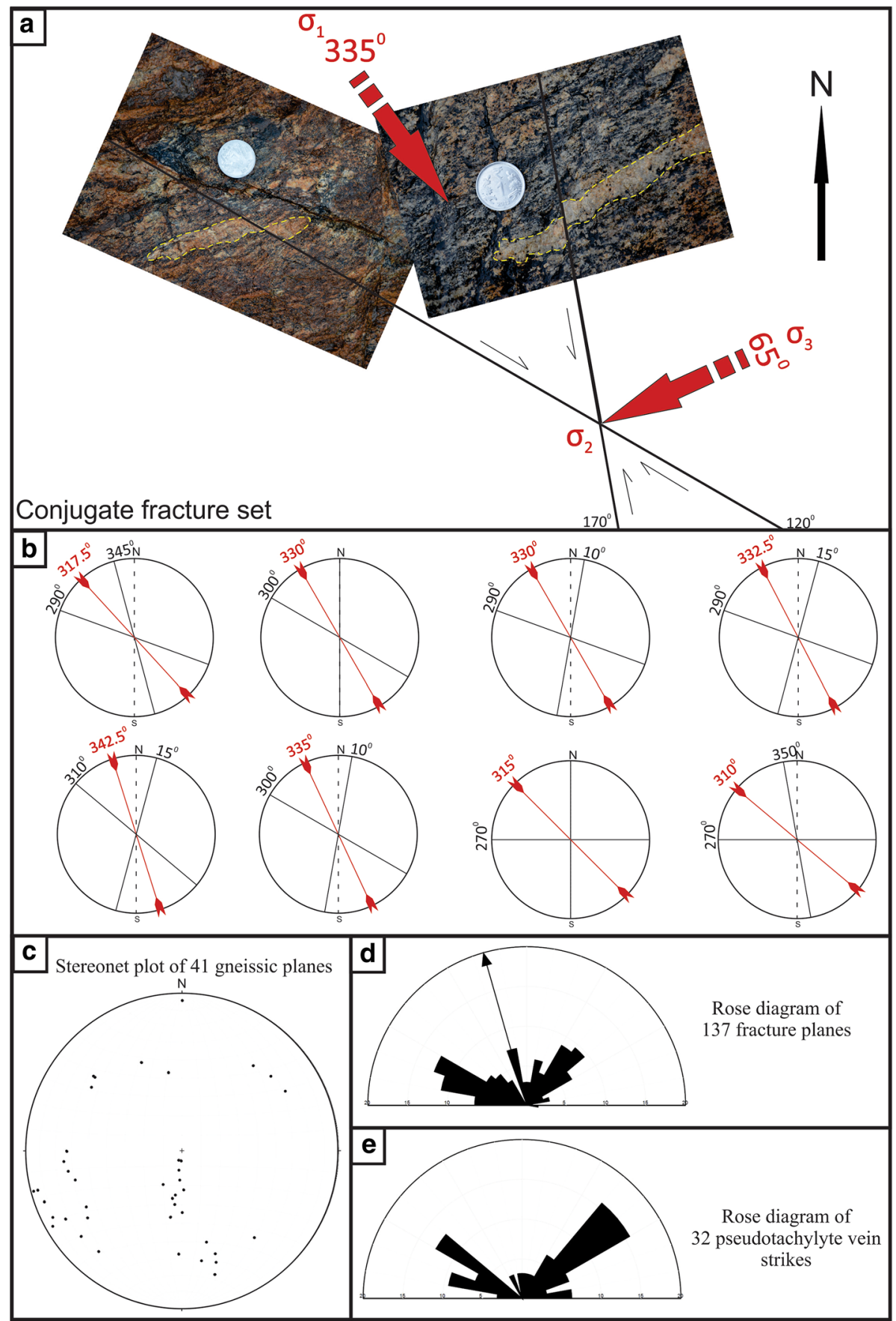

Figure 2. (a) Conjugate set of strike slip fractures in the same outcrop of Tonalite-Trondhjemite-Gneiss near Salem. One set of fracture strikes $120^{\circ}$ (right lateral) and the other set $170^{\circ}$ (left lateral). From the acute angle principle the $\sigma_{1}$ direction is found to be $330^{\circ}, \sigma_{3}$ direction is $65^{\circ}$ and $\sigma_{2}$ is vertical, (b) eight such conjugate sets have been plotted in stereonet and $\sigma_{1}$ is found to vary between $310^{\circ}$ and $342^{\circ}$, (c) stereoplot of 41 gnessosity fabric from the charnockites and Tonalite-Trondhjemite-Gneiss, they show an E-W trend, (d) 137 fracture planes collected from Gangavalli Shear Zone plotted in the rose diagram, they show two prominent maxima, one is in NE direction and the other one is in the NW direction. The arrow indicates the compressive stress direction, (e) further, 32 pseudotachylyte veins have been plotted in a rose diagram, they show NE-SW and NW-SE prominent trend.

conjugate character (Ramsay and Huber 1987). We have analyzed eight such conjugate sets in stereonet and found the direction of principal stresses as $\sigma_{1}\left(310^{\circ}-342^{\circ}\right), \sigma_{2}$ (vertical) and $\sigma_{3}$ $\left(40^{\circ}-72^{\circ}\right)$ direction (figure $\left.2 \mathrm{~b}\right)$.

\subsection{Macroscopic study of pseudotachylyte vein}

Pseudotachylytes occur as dark veins within white to pink coloured charnockitic massif (figure $3 \mathrm{a}-\mathrm{f}$ ). These veins vary in thickness from few $\mathrm{mm}$ to tens 

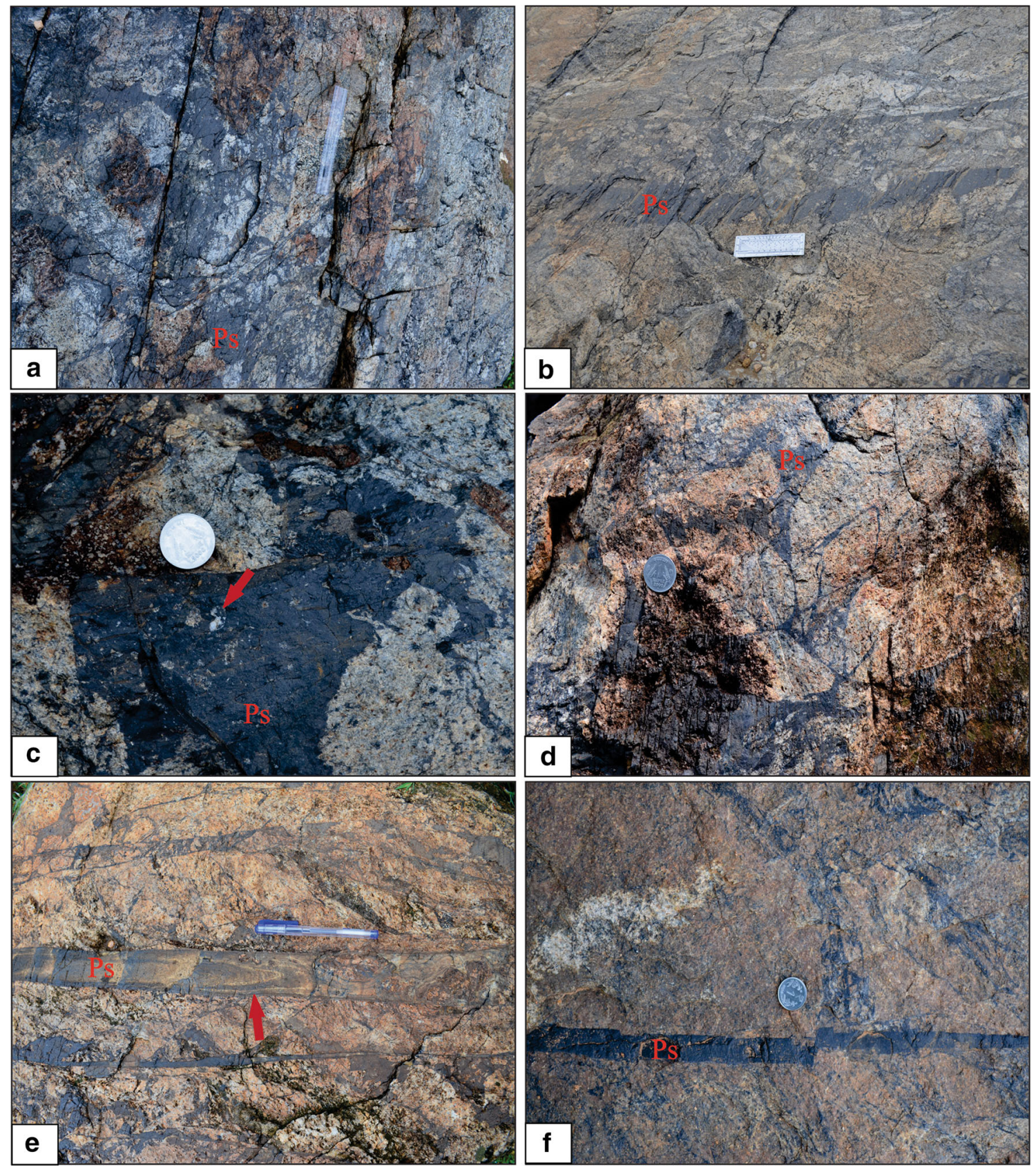

Figure 3. Dark pseudotachylyte veins (Ps) within the white to pink colored charnockitic massif. (a) Prominent fracture set (parallel to scale) in the charnockite, pseudotachylytes are emplaced along the fractures, (b) thick (7-8 cm) and straight pseudotachylyte veins showing a tapering end are emplaced along the gneissic fabric, (c) a patchy pseudotachylyte mass consists of country rock clasts (marked by red arrow), (d) thin pseudotachylyte veins produce anastomose network with dendritic connection, (e) poiseuille flow folding (also documented as sheath like fold structure by Berlenbach and Roering 1992) within a straight pseudotachylyte vein, marked by red arrow and (f) a thin pseudotachylyte vein is distinctly cross cut by another pseudotachylyte vein of about 1-cm thickness suggesting multiple phases of intrusion (displaced by $\sim 0.5 \mathrm{~cm}$ ).

of $\mathrm{cm}$. They not only intrude along the fractures but are also emplaced along the gneissic fabric of the rock (figure 3a, b). Gneissic parallel veins have a thickness of $7-8 \mathrm{~cm}$ and are generally straight with tapering and splay ends. The gneissic fabric is in $\mathrm{E}-\mathrm{W}$ direction while the fractures are in NE-SW and NW-SE directions (figures 1, 2c, d). Though the gneissic fabric is at a high angle to fractures, the pseudotachylyte melt pressure was high enough to overcome the tectonic stress across the gneissic planes and dilate them (Jolly and Sanderson 1997). Hence the pseudotachylytes veins show varied orientation from NE-SW to E-W and NW-SE (figure 2e). Patchy pseudotachylyte masses with clasts are observed within charnockites (figure $3 \mathrm{c})$. Thinner veins $(1 \mathrm{~mm}-1 \mathrm{~cm}$ 
thick) produce anastomose network with dendritic connections, in the process, they enclose rounded to elliptical country rock fragments (figure $3 \mathrm{~d}$ ). The veins assume triangular geometry in section due to infilling in the interclastal spaces. Further, the flow structure of pseudotachylyte veins is noticed in the form of folds resembling Poiseuille flow (figure 3e). Multiple intrusions are seen from the cross cut relationship of the veins (figure $3 \mathrm{f}$ ), however, from their mutual intersection, it has been interpreted that they belong to a prolonged period of fracturing and intrusion.

\subsection{Microscopic study of pseudotachylyte vein}

Pseudotachylytes under the microscope appear as grey to dark brown under plane polarized light and isotropic (i.e., as it is glassy) under crossed polar (figure $2.2 \mathrm{a}-\mathrm{h}$ ). The host rock minerals namely hypersthene, quartz and feldspars are fractured into rectangular or lensoidal pieces close to the vein margin (figure 2.2a). Hypersthene does not show alteration to hornblende or biotite suggesting an anhydrous condition during brittle deformation. In a few instances, quartz grains have assumed lensoidal geometry with undulose extinction suggesting crystal plastic deformation due to a higher temperature in near vicinity of the vein. However, ductile deformation is absent a little away from the vein margin, suggesting a steep thermal gradient (figure 2.2b). Tensile cracks are developed in the adjoining minerals at a right angle to the direction of the vein, as a result, pseudotachylytic offshoots have impinged into the wall rock (figure 2.2c). In many instances, both grey and dark brown pseudotachylyte melts are observed within the same vein reflecting a viscosity contrast (figure 2.2d; Spray 1993). Veins show lamellar flow indicated by alignment of elongated quartz clasts parallel to vein wall (figure 2.2e) and turbulent flow folds (figure 2.2f). Cortex clasts are observed due to the accumulation of ferrugenised pulverized mass around clast (figure 2.2g; Rowe and Griffith 2015). A few clasts have undergone displacement along the fractures within the vein (figure 2.2f). Assimilated clasts have attained a high degree of roundness due to the melting of the asperities around the grain margin (figure 2.2f; Ray 2004). Devitrifications of veins have occurred at several places producing microlites (figure 2.2h). Detailed study of these microlites indicates that these can be classified into two groups, as a 'simple group' and 'complex group' (Lin 1994b). While the former is of acicular nature and form during the flow of the melt with directive texture around the clasts, the latter possesses a sheaf and spherulitic form and develops with increasing grain size (e.g., 10-20 $\mu \mathrm{m}$ ) towards the center of the vein (Lin 1991, 1994b).

\subsection{Chemical analysis, XRD and EPMA study}

Chemical analysis of the glassy matrix of the pseudotachylyte veins by Electron probe Micro Analyzer (EPMA) shows $\mathrm{SiO}_{2}=60.89-75.34 \%$, $\mathrm{FeO}=0.26-2 \%, \mathrm{Na}_{2} \mathrm{O}=8 \%$; this suggests that the pseudotachylyte melt is acidic in nature, comparable with that of charnockites. Melt having $75.34 \% \mathrm{SiO}_{2}$ is suggestive of a higher amount of quartz having participated in the melting. Hypersthenes in the host rock have contributed $\mathrm{FeO}$ to the melt. Additionally, XRD study of the quartz clasts reflects hexagonal beta quartz in the composition that melts around $1550^{\circ} \mathrm{C}$ (Heaney 1994; Jiang et al. 2015); melting of the clasts has given rise to high degree of roundness. Further, EPMA study suggests the microlites are albitic in composition $\left(\mathrm{SiO}_{2}=60.0-68.86 \%, \mathrm{Na}_{2} \mathrm{O}=4.7-7.9 \%\right)$. Albite crystallizes at $\sim 1100^{\circ} \mathrm{C}$ (Navrotsky et al. 1982). From all these angles it leads to the implication that the pseudotachylyte melt has been generated at $>1000^{\circ} \mathrm{C}$ suggesting an ultrahigh temperature condition.

Figure 4. Pseudotachylyte appears grey to dark brown in plane polarized light and isotropic under crossed Nicol. (a) Hypersthene (Hy), plagioclase $(\mathrm{Pl})$ and quartz $(\mathrm{Q})$ are cut into rectangular pieces near Pseudotachylyte (Ps) veins. No alteration is observed in hypersthene, suggesting dry condition during deformation, (b) the quartz grains close to pseudotachylyte vein (Ps) show ductile deformation with undulose extinction suggesting high temperature of deformation close to vein wall, (c) Quartz close to the vein wall show tensile crack right angle to vein elongation, suggesting extension. Pseudotachylyte melts have impinged along these tensile cracks (marked by arrow), (d) thick pseudotachylyte vein tapering towards left possess both grey and dark brown melt in a single vein suggesting viscosity contrast (arrow indicates the flow direction), (e) elongated quartz clasts are aligned parallel to the flow direction indicating a lamellar flow in the melt, (f) pseudotachylyte vein show open fold pattern indicating a turbulent flow during melt injection. Some of the clasts are fractured, and few show high degree of roundness, (g) cortex clasts marked by dark ferruginous crushed material deposited around the clasts, and (h) devitrification of glass into microlites producing radiating spherulitic structure. 

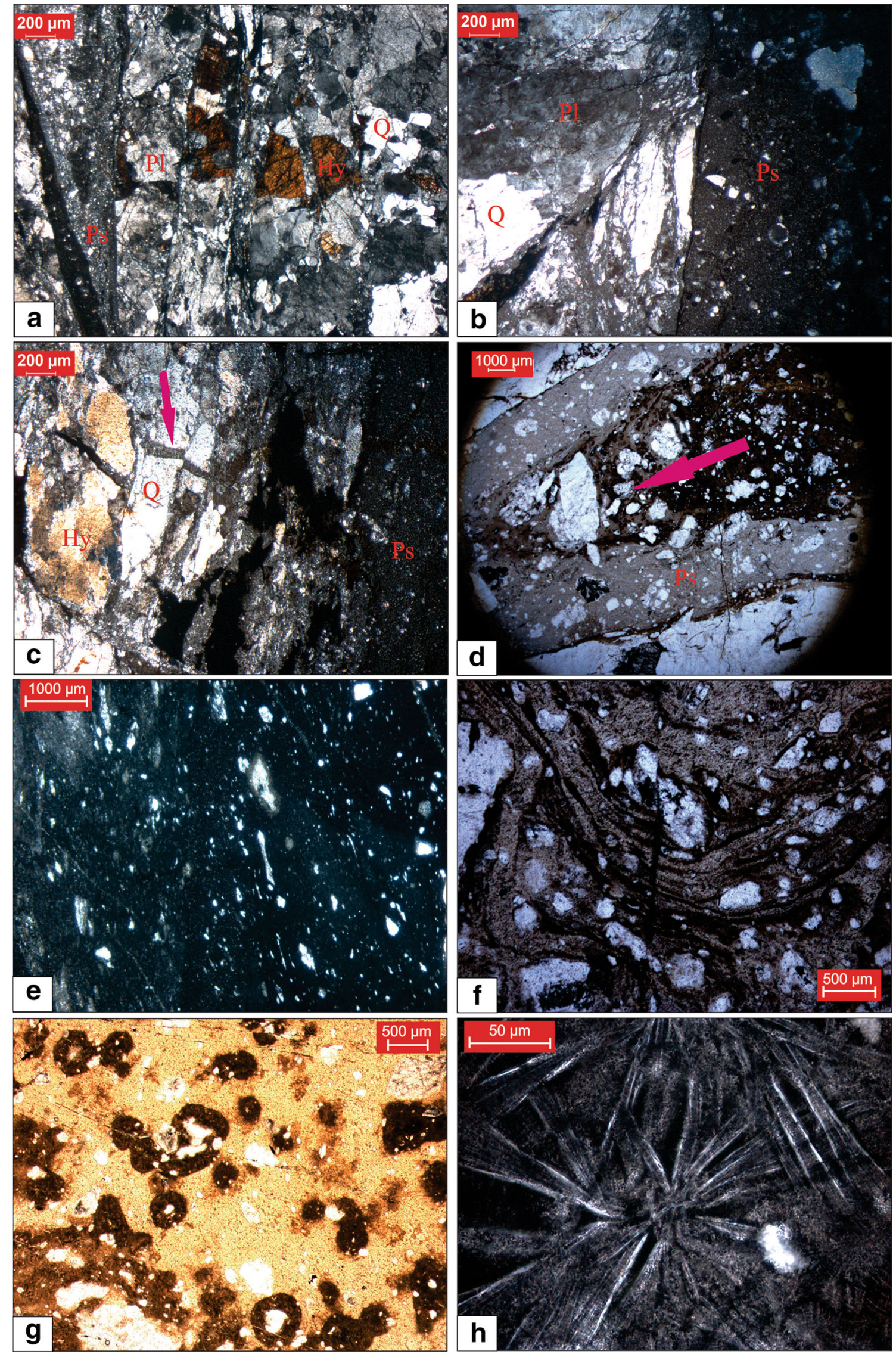


\section{Statistical analysis of clasts}

Measurement and statistical approach of embedded clasts in the pseudotachylyte veins are now gaining a widespread acknowledgement and are used to analyze, quantitatively, the processes of formation of the melt, relationship with country rock, mode of evolution and more precisely a pictorial representation including modeling. As two views are held regarding the formation of pseudotachylytes, here clast size analysis and roundness of clasts are considered to quantify the process of formation of pseudotachylytes in GSZ. In order to characterize the kilometre-scale geometry of pseudotachylyte veins in the GSZ, a segment of the central branch along the NNE-SSW stand out ridge was mapped on toposheet at 1:50,000 scale (figure 1). The samples of pseudotachylyte body, which show different vein geometry at the local outcrops (figure 3) were collected for microscopic analysis.

\subsection{Clast-size analysis}

Under the microscope, the polished image surfaces of the pseudotachylytes show that the rocks consist of clasts of varying sizes set in a fine-grained matrix. Because of their optical contrast with the matrix, these clasts stand out prominently in thin section. However, the nature of the matrix is variable, thus permitting recognition of clasts in matrix domains (Hetzel et al. 1996). The method used for analysis of clast size-frequency distribution in pseudotachylyte is a 2-dimensional method, where the measurement of areas of the clasts was made in a plane in thin section. Photomicrographs of the thin sections were taken, dividing them into grids of $1 \times 1 \mathrm{~mm}$ using a transparent sheet. An image enhancement software called 'imageJ' was used for processing the images and enhancing their contrast, and for setting intensity thresholds, making the image binary (black representing clasts and white as background matrix, as can be seen in figure 5 ( $\mathrm{a}$ and $\mathrm{b}$ ), and each clasts has been measured for area, major and minor axes and roundness. The set parameter used for the area is 30 $10,00,000 \mu^{2}$ (taking the average radius of clasts as more than $5 \mu \mathrm{m})$. Clasts smaller than $30 \mu \mathrm{m}^{2}$ are not included for the analysis as very fine-grained clasts are difficult to measure.

The generated data file was processed further and the erroneous data corresponding to (a) the mineral-filled cracks which are taken by 'imageJ' as clasts (because of their brightness), and (b) the clasts which occur partly within and partly outside the window frame are not taken into consideration. These modifications are carried out by visual examination of the image by cross-checking the processed image with the respective original photomicrograph to minimize errors.

Before the onset of melting along frictional interfaces, the wall rock of seismic faults is crushed to generate a Power-law grain-size distribution pattern, which gets modified after the fusion of clasts due to heat transfer melting. The clast size $(u)$ and the number of clasts $(N)$ (i.e., frequency ' $f$ ') can be plotted along the $\mathrm{X}$ - and $\mathrm{Y}$-axes, respectively. These $\log -\log$ plots of ' $u$ vs. $N$ ' show straight-line graphs, whose general expression is defined by the following equation:

$$
\log N=\log c-D \log u
$$

where $N$ represents the number of grains (frequency, $f$ ) of size $u, D$ is the slope of the straight line and $c$ is a constant. This expression can be written as:

$$
N=c u^{-D} \text {. }
$$

As a general expression for Power law distribution and the exponent $D$ is a fractal dimension. The data for size (area in $\mu \mathrm{m}^{2}$ ) and a number of clasts $(N)$ is used to construct log-log graphs, based on Power law size distribution. The fractal dimension $D$ or slope of the best fit line can be determined from the auto generated equation using MS excel sheet (figure 6a, b).

\subsection{Roundness of clasts (Rd)}

The aim of the roundness analysis was to determine the roundness of the lithic clasts embedded in the matrix of the pseudotachylyte veins. This is in order to quantify the roundness factor of these clasts and establish its application as one of the indicators of either melting or the crushing origin of these pseudotachylytes, to understand the process and mechanism of its formation. Roundness $(R d)$ is the summation of the ratio of $(r i / R)$ and $n$, as defined by Wadell (1936) in one plane (figure 7).

The equation is

$$
R d=\sum\left(\frac{r i}{R}\right) / n,
$$

where $r i$ is the radius of curvature of the corner, $R$ is the radius of the maximum inscribed circle and $n$ is the number of corners of the clasts in the 

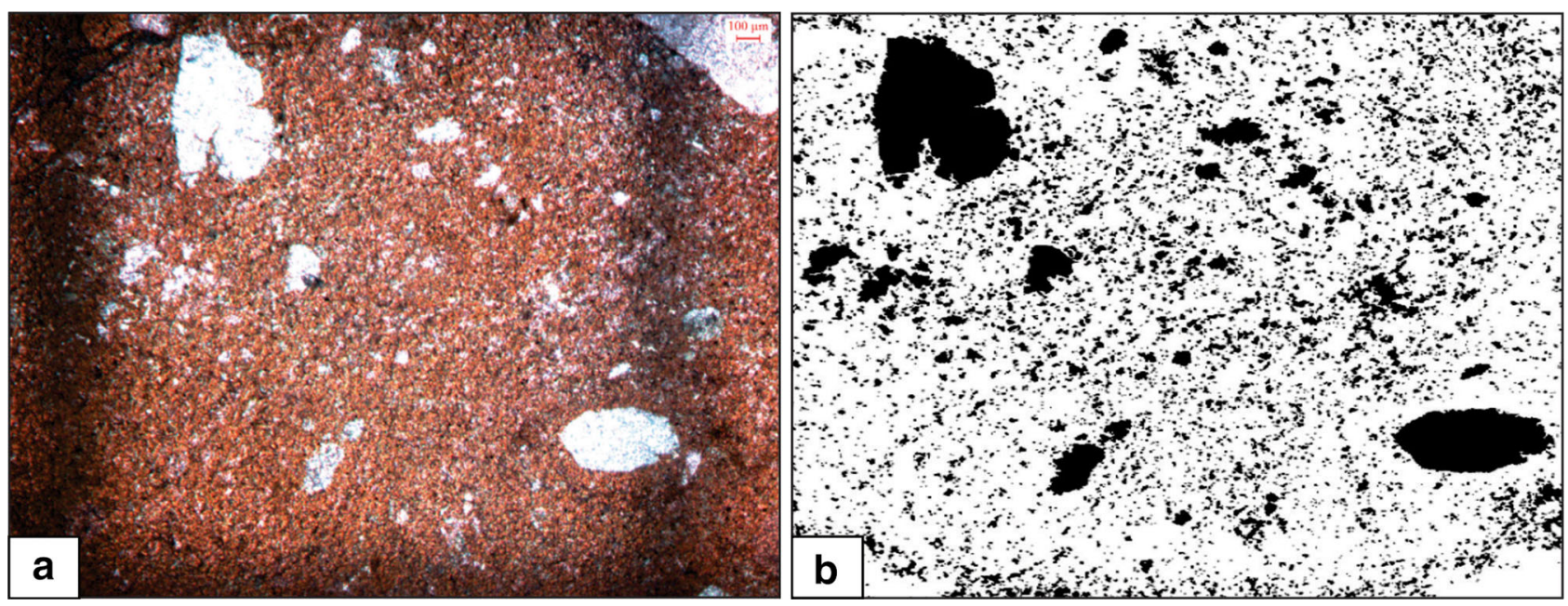

Figure 5. (a) Photomicrograph of pseudotachylyte under plane polarized light, brighter clasts and brown glassy matrix, one grid of $1 \times 1 \mathrm{~mm}$ (dark square), and (b) same photo processed to binary image through 'imageJ' software to measure clast size for size-frequency analysis.
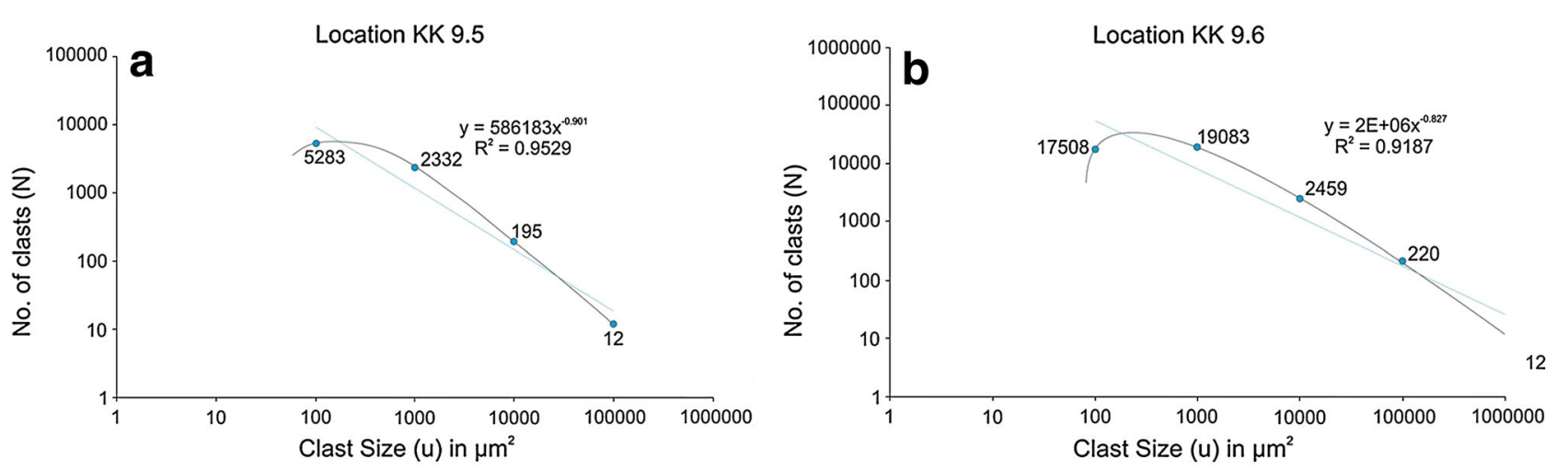

Figure 6. $\log -\log$ graph of size $(u$, in terms of area) against frequency $(N)$, indicates a modified Power law distribution.

given plane. The maximum value for the roundness achieved by the formula is 1.0 .

\section{Results}

The graphs (figure 6a, b) are plotted taking clast size on the $\mathrm{x}$-axis and the number of clasts on the y-axis, both in logarithmic scales. These $N-u$ loglog graphs for both the locations follow the Power law size-frequency distribution pattern, but with a modification as we approach the population of the finer clasts. The straight line is the best fit line, which shows a 'left-hand fall-off'. These diagrams show that the finer clasts population follows a modified size distribution pattern. The points on the $\mathrm{N}-\mathrm{u}$ plot are broadly distributed along a straight line, with some points distributed far away from the line of best fit, mainly because of fall-off of the points at the lower values of $u$. The linearity in $\log -\log$ scale indicates the existence of 'self-similarity pattern' in the process of fragmentation. The fractal dimension is a statistical index of complexity comparing the detailed observation in a pattern change with the scale variation at which it is measured and indicates how a data point is closely approaching to a certain geometrical dimension. Here we noticed that the $D$ value is very close to one dimension and varies between 0.827 and 0.901 (table 4). In both the graphs, the lower threshold value of clast size, where the left hand fall-off started, is indicated by $1000 \mu \mathrm{m}^{2}$ (tables 1 , 2 ). Hence, it is suggesting a single event origin of pseudotachylyte vein at both locations.

The equation from the graph (figure 6b) includes a deviation term ' $\mathrm{E}$ ' which indicates the uncertainty in the observed value. When $u$ approaches zero, $N$ produces a large number. According to 

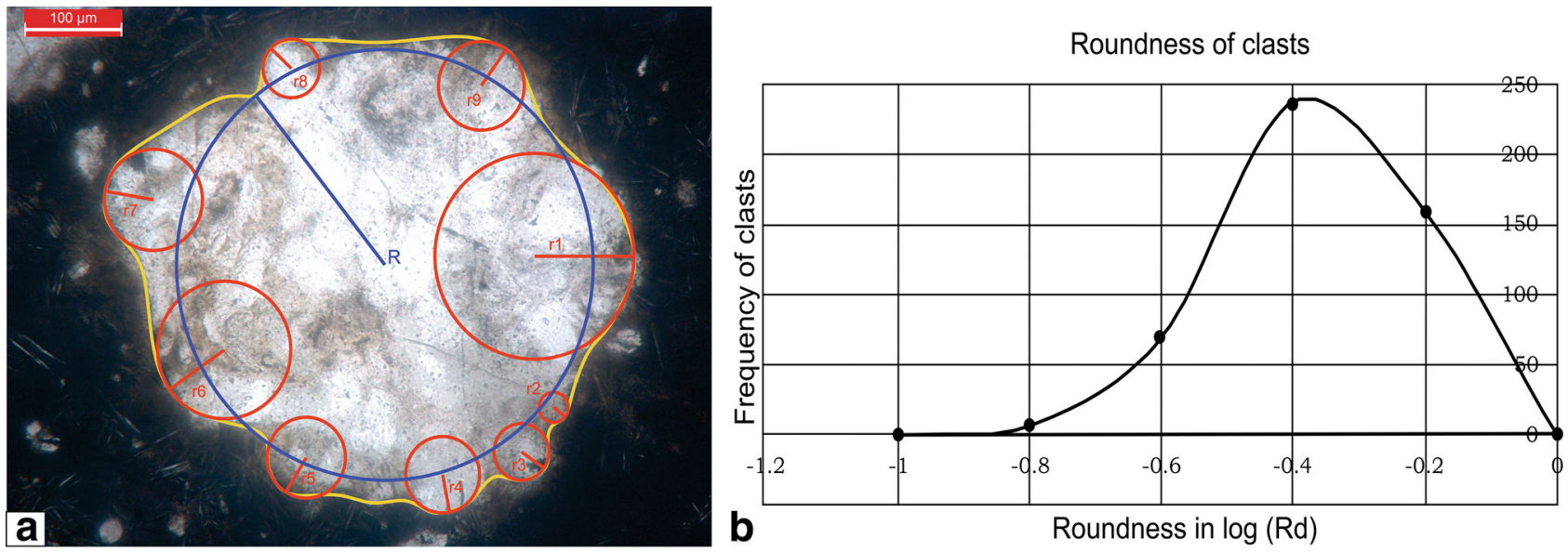

Figure 7. (a) Photomicrograph shows the measurement of roundness of clast within dark matrix. Small circles at each corner are drawn to measure the radius of curvature, and (b) graph between clasts frequency against logarithm of roundness produces a Boltzman distribution of clasts where more roundness is achieved to the right of the x-axis. Maximum number of clasts attend 0.4 roundness.

Table 1. Frequency of the clasts with areas. Location KK 9.5 (photomicrographs taken @ $5 \times$ optical magnification).

\begin{tabular}{lcc}
\hline $\begin{array}{l}\text { Area } \\
\left(\mu \mathrm{m}^{2}\right)\end{array}$ & Frequency & \\
\hline 100 & 5283 & \\
1000 & 2332 & \\
10,000 & 195 & \\
100,000 & 12 & \\
Total clasts & 7822 & $\mathrm{D}=0.901$ \\
\hline
\end{tabular}

Table 2. Frequency of the clasts with areas. Location KK 9.6 (photomicrographs taken @ $10 \times$ optical magnification).

\begin{tabular}{lcc}
\hline $\begin{array}{l}\text { Area } \\
\left(\mu \mathrm{m}^{2}\right)\end{array}$ & Frequency & \\
\hline 100 & 17,508 & \\
1000 & 19,083 & \\
10,000 & 2459 & \\
100,000 & 220 & \\
$1,000,000$ & 12 & \\
Total clasts & 39,282 & $\mathrm{D}=0.827$ \\
\hline
\end{tabular}

the Power law distribution, the frictional process should produce a large population of finer clasts than the previous clasts size in the subsequent fragmentation stages. But this continuity is broken down at a certain point. So, Power law holds good when $u>u_{\text {min }}$, where $u_{\text {min }}$ is measured as $1000 \mu \mathrm{m}^{2}$ for both samples.

A similar software 'imageJ' was used for the roundness study. Measurements were done on the
Table 3. Frequency (N) of the clasts and their roundness $(R d)$.

\begin{tabular}{lccc}
\hline $\begin{array}{l}\text { Roundness } \\
(\mathrm{Rd})\end{array}$ & $\log (\mathrm{Rd})$ & $\begin{array}{c}\text { No. of } \\
\text { clasts }(N)\end{array}$ & $\begin{array}{c}\text { Clast } \\
\text { frequency }(\%)\end{array}$ \\
\hline 0.1 & -1 & 19 & 0.048 \\
0.2 & -0.699 & 510 & 1.29 \\
0.3 & -0.5229 & 2539 & 6.46 \\
0.4 & -0.3979 & 5363 & 13.65 \\
0.5 & -0.301 & 7174 & 18.26 \\
0.6 & -0.2218 & 7914 & 20.15 \\
0.7 & -0.1549 & 7238 & 18.42 \\
0.8 & -0.0969 & 5905 & 15.03 \\
0.9 & -0.0458 & 2332 & 5.93 \\
1 & 0 & 287 & 0.73 \\
Total & & 39,282 & 100 \\
\hline
\end{tabular}

clasts with an average diameter $>10 \mu \mathrm{m}$. The calculation was done as per the formula shown in equation (3). The results are plotted as roundness (on the x-axis) vs. frequency (on the y-axis) diagrams. Since the maximum value for roundness is 1.0, when plotted as $\log (\mathrm{Rd})$, the values along the $\mathrm{x}$-axis becomes negative, because the logarithmic value of maximum roundness 1 is zero, so further finer clasts will lie on the left side of the $\mathrm{x}$ axis. The roundness analysis shows that $\mathrm{Rd}$ varies from 0.1 to 1.0 (table 3 ) and about $80 \%$ of clasts have roundness $>0.4$ in the sample pseudotachylyte (figure 7b). Lin (1999) has documented that roundness $<0.4$ are indicative of cataclastic rocks and crushing originated pseudotachylyte, whereas roundness $>0.4$ are from melting originated pseudotachylyte. This result proposes that these clasts would have been reshaped by melting rather 
Table 4. Details of the images analyzed and characteristics of the clast-size distribution.

\begin{tabular}{|c|c|c|c|c|}
\hline Sl. no. & $\begin{array}{l}\text { Sample } \\
\text { no. }\end{array}$ & $\begin{array}{c}\text { Area occupied by } \\
\text { clasts within } \\
\text { window }(\%)\end{array}$ & $\begin{array}{c}D \text {-value obtained } \\
\text { by } N-u \text { graph }\end{array}$ & $\begin{array}{l}\text { No. of } \\
\text { clasts }\end{array}$ \\
\hline 1 & KK 9.5 & 16.88 & 0.901 & 7822 \\
\hline 2 & KK 9.6 & 7.98 & 0.827 & 39,282 \\
\hline
\end{tabular}

than crushing or fracturing. The rounded and embayed clasts set in the matrix in pseudotachylytes are commonly considered to be indicative of melting rather than crushing origin (Shand 1916; Philpots 1964; Sibson 1975; Wallace 1976; Allen 1979; Maddock 1983; Magloughlin 1992; Lin 1994a, b, 1996).

Measurement of clasts area from both the thin sections indicates that a maximum of $17 \%$ area is covered by the clasts (table 4). So, all the pseudotachylyte veins originated from the GSZ are matrix rich or melt dominated (table 4).

\section{Discussion}

It has been a debate between two school of thoughts on the formation of pseudotachylyte, i.e., (a) the ultra-comminution (cataclasis) views (Wenk 1978) and (b) the rock fusion views (Shimamoto and Nagahama 1992). However, the opinion in favour of melt origin outweighs against the crush origin based on the size distribution of the clasts within the pseudotachylyte vein, where clasts follow a deviated Power law in size vs. frequency curve in log scale (Spray and Thompson 1995; Ray 1999, 2004). Figure 6 shows the bending of the linear curve at its tip indicating the effect of melting during the comminution process of the host rock. The abundance of finer grains (e.g., $<500 \mu^{2}$ ) is not proportionate with the Power law distribution. So, the Power law distribution of a comminution process has always borne a threshold size range, which may be set up by the grain boundary decrepitating under an ultra-high temperature condition. This modified Power law can be considered as a proxy for the rock fusion involvement at some high heat localized area during the block friction along the fault plane. Further, measurement of clasts area indicates that a maximum of $17 \%$ area is covered by the clasts (table 4). So, the pseudotachylyte veins originated from the GSZ are matrix rich or melt dominated (table 4). Here we noticed that the $D$ value is very close to one dimension and varies between 0.827 and 0.901 (table 4). From equation 2, fractal dimension $D$ represents a gentle slope line of the Power law size distribution graph. $D$ values in reported natural pseudotachylyte occurrences vary from $>0.5$ to 2.9991 (Ray 2004) where $D>2$ is obtained from experimental pseudotachylyte melt (Tsutsumi 1999). $D$ has also a large value for gauge, breccia, cataclasites, etc. (Glazner and Mills 2012). Higher the values, lower is the range of clast size exhibited by the pseudotachylytes. Less $D$ values indicate a higher range of clasts size. In cataclasites, there is a direct relationship between $D$ values and strain (Marone and Scholz 1989). The GSZ displays lower $D$ values, indicating a large range of size distribution. As the pseudotachylytes are produced by high strain rate brittle deformation (Shimamoto and Nagahama 1992), we are suggesting that the lower $D$ values in GSZ is attributable to the combined process of crushing and melting of the clasts.

There are many ways to get roundness of a grain, which tells its process involved during the formation. But roundness gained by a mineral of magmatic origin can be explained with the help of the temperature condition of the melt; the temperature for the pseudotachylyte melt generation is around $1100^{\circ} \mathrm{C}$ (Sibson 1975). From the above roundness analysis, we can say the clasts in these pseudotachylyte veins were rounded by frictional melting rather than by crushing or fracturing or chipping in the host charnockite and hence, the roundness can be used as an index for evaluating the formation process and origin of pseudotachylyte.

Apart from this, the melt origin of pseudotachylyte is also proven by the microlites present in the pseudotachylyte body. Microlites indicate the devitrification process of the melts. When a melt intrudes a cold country rock, it quenches to give rise to glassy rock (Ray 2004). Devitrification of glass into microcrystals called microlites takes place as the temperature drops. Hence, microlites reflect the composition and temperature of the melt. The GSZ shows albitic microlites suggesting a temperature of crystallization around $1000^{\circ} \mathrm{C}$. Hence, the 
temperature of the melt would be much higher than this. Further, the clasts show pure hexagonal $\beta$ quartz, and as these quartz minerals have undergone melting, the temperature would be around $1550^{\circ} \mathrm{C}$.

Association of pseudotachylytes with high-grade rocks have been interpreted to be close to plate margin faults where the plates undergo high frictional strain that leads to seismicity and melting of the rocks (Sibson 1986; Austrheim and Boundy 1994; Scholz 1998; Steltenpohl et al. 2006). Thus pseudotachylyte is a good indicator of paleoseismic events (e.g., Sibson 1975; Ikesawa et al. 2003; Lin et al. 2005). The GSZ probably defines close to the Precambrian plate margin (equivalent of Jhavadi Fault). The terranes lying on either side belong to two different plates (Sharma et al. 2015).

\section{Conclusion}

In outcrop, pseudotachylytes exist in a wide variety of forms in the GSZ including fault veins, injection veins that branch out at a high angle and irregularly shaped injection veins complexly interconnected in a network called anastomose vein. The regional compression in Gangavalli area is measured as a NNW direction that leads to the development of two prominent sets of fractures, e.g., $0^{\circ}-15^{\circ}$ and $270^{\circ}-300^{\circ}$. Pseudotachylyte veins are oriented along one of its dominant fracture set along NNE direction. This can be concluded that the GSZ is marked by a fast slip frictional event occur along NNE direction. This seismic related friction leads to the formation of numerous fractures as well as intruded by pseudotachylyte melts. From the modified Power law of size and frequency distribution graph, it can be suggested that the friction caused during block slip creates a localized melt in the cataclasite rock under brittle deformation. This evidence is further confirmed by the roundness study of clasts within the pseudotachylyte melt, which may have reached a temperature of $1100^{\circ}-1500^{\circ} \mathrm{C}$ for the production of pseudotachylyte melts from the host charnockite.

\section{Acknowledgements}

Authors are greatly thankful to the Head of the Department of Earth Sciences, Indian Institute of Technology, Bombay for the permission and funding to carry put fieldwork in and around Gangavalli area, Salem, Tamil Nadu. They also convey their gratitude to B Sivalingam (JRF at IIT Bombay) and Sridharan, Thiyaga Ranjan and Madan Raj (Students of Department of Geology, Govt. Arts College, Salem, Tamil Nadu) for their extensive support and help during the field visit. Critical reviews by Dr. Surajit Mishra, BGRL, Govt. of India and the other anonymous reviewer helped in improving the quality of the manuscript.

\section{References}

Allen A R 1979 Mechanism of frictional fusion in fault zones; J. Struct. Geol. 1 231-243.

Austrheim H and Boundy T M 1994 Pseudotachylytes generated during seismic faulting and eclogitization of the deep crust; Science 265(5168) 82-83.

Berlenbach J W and Roering C 1992 Sheath-fold-like structures in pseudotachylytes; J. Struct. Geol. 14(7) 847-856.

Bhaskar Rao Y J, Kelley S P, Harris N B W, Narayana B L and Srikantappa C 2006 An 40 Ar-39 Ar laser-probe study of pseudotachylites in charnockite gneisses from the Cauvery Shear Zone system, south India; Gondwana Res. 10(3) 357-362.

Bischoff A A 1982 The pseudotachylite of the Vredefort Dome; Trans. Geol. Soc. S. Africa 65 207-225.

Biswal T K, Sarkar S, Pal A and Chakraborty U 2004 Pseudotachylites of the Kui-Chitraseni shear zones of the Precambrian Aravalli Mountain, Rajasthan; J. Geol. Soc. India 64 325-335.

Biswal T K, Thirukumaran V, Ratre Kamleshwar and Sundaralingam K 2009 Study of the Salem-Attur shear zone, east of Salem, Tamil Nadu: A new kinematic interpretation; Curr. Sci. 96(10) 1-4.

Bizzarri A 2014 The destiny of a clast within a molten pseudotachylyte vein; Bull. Seismol. Soc. Am. 104(5) 2399-2411.

Cardwell R K, Chinn D S, Moore G F and Turcotte D L 1978 Frictional heating on a fault zone with finite thickness; Geophys. J. Roy. Astron. Soc. 52 525-530.

Clark C, Collins A S, Timms N E, Kinny P D, Chetty T R $\mathrm{K}$ and Santosh M 2009 SHRIMP U-Pb age constraints on magmatism and high-grade metamorphism in the Salem Block, southern India; Gondwana Res. 16 27-36.

Glazner A F and Mills R D 2012 Interpreting twodimensional cuts through broken geologic objects: Fractal and non-fractal size distributions; Geosphere 8(4) 902914.

Grieve R A F 1975 The petrology and chemistry of the impact melt at Mistastin Lake Crater, Labrador; Bull. Geol. Soc. Am. 86 1617-1629.

Han R, Hirose T and Shimamoto T 2010 Strong velocity weakening and powder lubrication of simulated carbonate faults at seismic slip rates; J. Geophys. Res. Solid Earth 115 B3, doi:10.1029/2008JB006136.

Heaney P J 1994 Structure and chemistry of the low-pressure silica polymorphs; Rev. Mineral. Geochem. 29(1) 1-40.

Hetzel R, Altenberger U and Strecker M R 1996 Structural and chemical evolution of pseudotachylytes during seismic events; Mineral. Petrol. 58(1-2) 33-50. 
Ikesawa E, Sakaguchi A and Kimura G 2003 Pseudotachylyte from an ancient accretionary complex: Evidence for melt generation during seismic slip along a master decollement?; Geology 31(7) 637-640.

Jiang H, Lee C T A, Morgan J K and Ross C H 2015 Geochemistry and thermodynamics of an earthquake: A case study of pseudotachylites within mylonitic granitoid; Earth Planet. Sci. Lett. 430 235-248.

Jolly R J H and Sanderson D J 1997 A Mohr circle construction for the opening of a pre-existing fracture; J. Struct. Geol. 19(6) 887-892.

Kirkpatrick J D, Dobson K J, Mark D F, Shipton Z K, Brodsky E E and Stuart F M 2012 The depth of pseudotachylyte formation from detailed thermochronology and constraints on coseismic stress drop variability; J. Geophys. Res. Solid Earth 117 B6, doi:10.1029/ 2011JB008846.

Lin A 1991 Origin of fault-generated pseudotachylyte; Ph.D. Thesis, Tokyo University.

Lin A 1994a Glassy pseudotachylytes from the Fuyun fault zone, northwest China; J. Struct. Geol. 16 71-83.

Lin A 1994b Microlites morphology and chemistry in pseudotachylytes from Fuyun fault zone; J. Geol. 102 317-329.

Lin A 1996 Injections veins of crushing-originated pseudotachylytes and fault gauge formed during seismic faulting; Eng. Geol. 43(5) 213-224.

Lin A 1999 Roundness of clasts in pseudotachylytes and cataclastic rocks as an indicator of frictional melting; J. Struct. Geol. 21(5) 473-478.

Lin A, Maruyama T, Aaron S, Michibayashi K, Camacho A and Kano K I 2005 Propagation of seismic slip from brittle to ductile crust: Evidence from pseudotachylyte of the Woodroffe thrust, central Australia; Tectonophys. 402(1) 21-35.

Maddock R H 1983 Melt origin of fault-generated pseudotachylytes demonstrated by textures; Geology $\mathbf{1 1}(\mathbf{2})$ 105-108

Magloughlin J F 1992 Microstructural and chemical changes associated with cataclasis and friction melting at shallow crustal levels: The cataclasite and pseudotachylyte connection; Techtonophys. 204 243-260.

Marone C and Scholz C H 1989 Particle-size distribution and microstructures within simulated fault gouge; J. Struct. Geol. 11(7) 799-814.

McKenzie D and Brune J N 1972 Melting on fault planes during large earthquakes; Geophys. J. Intl. 29(1) 65-78.

Navrotsky A, Capobianco C and Stebbins J 1982 Some thermodynamic and experimental constraints on the melting of albite at atmospheric and high pressure; J. Geol. 679-698.

Niemeijer A, Di Toro G, Griffith W A, Bistacchi A, Smith S A and Nielsen S 2012 Inferring earthquake physics and chemistry using an integrated field and laboratory approach; J. Struct. Geol. 39 2-36.

Passchier C W 1982 Pseudotachylyte and the development of ultramylonite bands in the Saint-Barthelemy Massif, French Pyrenees; J. Struct. Geol.4(1) 69-79.

Pati J K, Reimold W U, Greshake A, Schmitt R T, Koeberl C, Pati P and Prakash K 2015 Pseudotachylitic breccia from the Dhala impact structure, north-central India: Texture, Mineralogy and Geochemical characterization; Tectonophys. 649 18-32.
Philpots A R 1964 Origin of pseudotachyletes; Am. J. Sci. 262(8) 1008-1035.

Ramsay J G and Huber M I 1987 The techniques of modern structural geology: Folds and fractures; vol. 2, Academic Press, New York.

Ray S K 1999 Transformation of cataclastically deformed rocks to pseudotachylyte by pervasion of frictional melt: Inferences from clast-size analysis; Tectonophys. 301 (3-4) 283-304.

Ray S K 2004 Melt-clast interaction and Power-law size distribution of clasts in pseudotachylytes; J. Struct. Geol. 26(10) 1831-1843.

Reimold W U and Collision W P 1992 Pseudotachylites of the Vredefort Dome and the surrounding Witwatersrand basin, South Africa; Geol. Soc. Am. Spec. Paper 293 177-196.

Rowe C D and Griffith W A 2015 Do faults preserve a record of seismic slip: A second opinion; J. Struct. Geol. 78 1-26.

Rowe C D, Fagereng A, Miller J A and Mapani B 2012 Signature of coseismic decarbonation in dolomitic fault rocks of the Naukluft Thrust, Namibia; Earth Planet. Sci. Lett. 333 200-210.

Scholz C H 1998 Earthquakes and friction laws; Nature 391(6662) 37-42.

Shand S J 1916 The pseudotachylyte of Parijs (Orange Free State), and its relation to 'trap- shotten gneiss' and 'flinty crush-rock'; Quart. J. Geol. Soc. London 72 198-221.

Sharma S D, Prathigadapa R, Kattamanchi S and Ramesh D S 2015 Seismological mapping of a geosuture in the Southern Granulite Province of India; Lithosphere $\mathbf{7}(\mathbf{2})$ 144-154.

Shimamoto T and Nagahama H 1992 An argument against the crush origin of pseudotachylytes based on the analysis of clast-size distribution; J. Struct. Geol. 14 999-1006.

Sibson R H 1986 Brecciation processes in fault zones: Inferences from earthquake rupturing; Pure Appl. Geophys. 124(1-2) 159-175.

Sibson R H 1975 Generation of pseudotachylites by ancient seismic faulting; Geophys. J. Roy. Astron. Soc. $43775-$ 794.

Spray J G 1992 A physical basis for the frictional melting of some rock forming minerals; Tectonophys. 204(3-4) 205-221.

Spray J G 1993 Viscosity determinations of some frictionally generated silicate melts: Implications for fault zone rheology at high strain rates; J. Geophys. Res.: Solid Earth 98(B5) 8053-8068.

Spray J G and Thompson L M 1995 Friction melt distribution in a multi-ring impact basin; Nature 373 130-132.

Steltenpohl M G, Kassos G and Andresen A 2006 Retrograded eclogite-facies pseudotachylytes as deepcrustal paleoseismic faults within continental basement of Lofoten, north Norway; Geosphere 2(1) 61-72.

Sundaralingam K 2013 Strain analysis, kinematic interpretation and tectonic evolution of Salem-Attur shear zone around Salem, Tamil Nadu, India; Ph.D. Thesis 2013, Department of Earth Sciences, Indian Institute of Technology Bombay.

Sundaralingam K, Biswal T K and Thirukumaran V 2012 Strain analysis of the Salem-Attur shear zone of Southern Granulite Terrane around Salem, Tamil Nadu; Rock Deformation and Structures RDS II (Nat. conf. Abstr.) 
124, Centre of Advanced Study in Geology University of Lucknow.

Swanson M T 1992 Fault structure, wear mechanisms and rupture processes in pseudotachylyte generation; Tectonophys. 204 223-242.

Thirukumaran V, Kumanan C J and Biswal T K 2014 Geoinformatic modeling of groundwater resource mapping of shear zone regions - A case study on Attur Valley, Tamil Nadu, India; J. Indian Soc. Remote Sens. 42(4) 789-800.

Tsutsumi A 1999 Size distribution of clasts in experimentally produced pseudotachylytes; J. Struct. Geol. 21(3) 305312 .

Corresponding editor: SAIBAL GUPTA
Ujiie K, Tsutsumi A and Kameda J 2011 Reproduction of thermal pressurization and fluidization of clay-rich fault gouges by high-velocity friction experiments and implications for seismic slip in natural faults; Geol. Soc. London Spec. Publ. 359(1) 267-285.

Wadell H 1936 Some practical sedimentation formulas; Geologiska Foreningen I Stockholm Forhandlingar 58(3) 397408.

Wallace R C 1976 Partial fusion along the Alpine Fault Zone, New Zealand; Geol. Soc. Am. Bull. 87 12251228 .

Wenk H R 1978 Are pseudotachylites products of fracture or fusion? Geology 6 507-511. 